\title{
Enantioselective Bromolactonization of Deactivated Olefinic Acids: Studies Toward the Synthesis of Brominated Isochroman-1,4-diones
}

\author{
Danqing $\mathrm{Li}^{\mathrm{a}}$ \\ Hailong $\mathrm{He}^{\mathrm{b} \dagger}$ \\ Xiaodan Huang ${ }^{\text {b }}$ \\ Pei Yu*c \\ Xiaojian Jiang*c (D) \\ a First Affiliated Hospital of Guangzhou University of Traditional \\ Chinese Medicine, Guangzhou 510405, P. R. of China

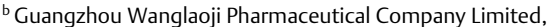 \\ Guangzhou 510450, P. R. of China \\ c Institute of New Drug Research and Guangzhou Key Laborato- \\ ry of Innovative Chemical Drug Research in Cardiocerebrovas- \\ cular Diseases, Jinan University College of Pharmacy, \\ Guangzhou 510632, P. R. of China \\ pennypeiyu@163.com \\ chemjxj2015@jnu.edu.cn \\ $\dagger$ These authors contributed equally to this work.
}

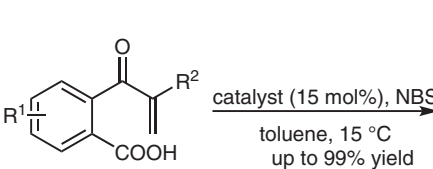

$\mathrm{R}^{1}=\mathrm{H}, \mathrm{Ar}, \mathrm{Cl}$

$\mathrm{R}^{2}=$ Alkyl, Aryl

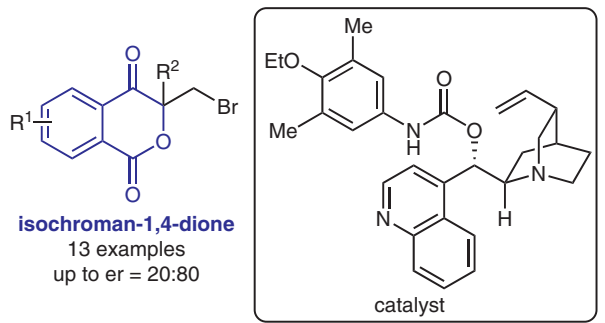

Received: 10.10 .2018

Accepted after revision: 02.11.2018

Published online: 22.11 .2018

DOI: 10.1055/s-0037-1610401; Art ID: so-2018-d0053-I

License terms: C)

Abstract Enantioselective bromolactonization using an aminocarbamate catalyst to generate brominated isochroman-1,4-diones is described. Excellent yields and moderate enantioselectivities were achieved.

Key words isochroman-1,4-diones, bromolactonization, organocatalysis, enantioselectivity, deactivated olefins

Isochroman-1,4-diones are useful building blocks for constructing a significant number of natural products and biologically active molecules. ${ }^{1}$ Although numerous synthetic methods have been developed for the construction of isochroman-1,4-diones, only one stereoselective strategy, employing a transition-metal catalyst to achieve a limited scope of products, has been reported. ${ }^{2}$ Therefore, development of useful methods to obtain diverse enantioenriched isochroman-1,4-diones is desirable. Catalytic enantioselective halocyclization of olefinic substrates is a useful strategy to obtain diverse important heterocyclic building blocks. ${ }^{3}$ We recently described a catalytic asymmetric halolactonization of $\alpha, \beta$-unsaturated ketone substrates 2 using aminourea $\mathbf{1}$ as a catalyst (Scheme 1 ). ${ }^{4}$ Various halo-lactone compounds 3 bearing a ketone moiety with high enantiomeric excess are achievable using deactivated olefinic acids. With substrates containing a ketone, we proposed that the reaction might not go through a classical double hydrogen-bond activation mechanism and the bulky, electron-donating substituent on the urea might exert steric and/or electronic effects in the enantioselective step.

In considering isochroman-1,4-dinone frameworks, we envisaged an intramolecular bromolactonization protocol. As shown in Scheme 1, the $\alpha, \beta$-unsaturated carboxylic acid substrate 4a might be converted into the corresponding enantioenriched bromo-substituted isochroman-1,4-dione $\mathbf{5 a}$ in the presence of $\mathrm{N}$-bromosuccinimide (NBS) and a suitable chiral catalyst. Herein, we disclose an organocatalytic process that produces brominated isochroman-1,4-diones by bromolactonization of prochiral precursors.

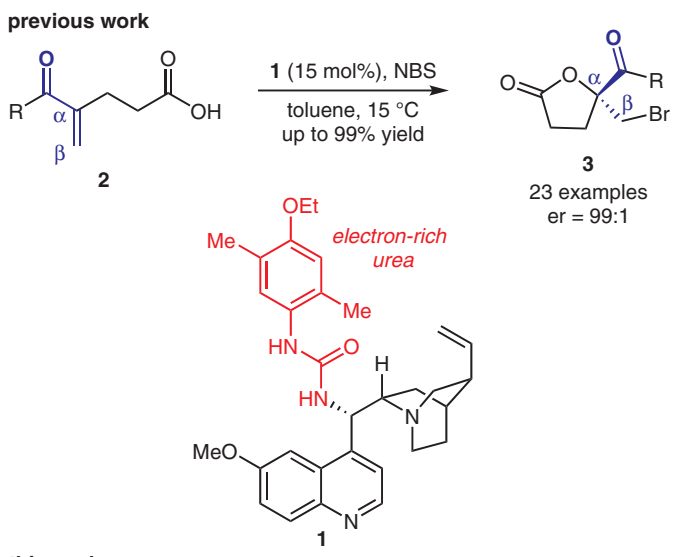

this work

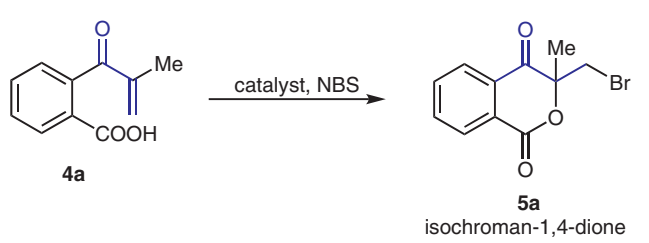

Scheme 1 Bromolactonization of deactivated olefinic acids 
To test this hypothesis, a number of catalysts were evaluated and the results are displayed in Scheme 2. Catalytic amounts of (DHQ) $)_{2}$ PHAL 6 or chiral phosphoric acids 7a and $\mathbf{7 b}$ delivered products with low er values. Unlike $\alpha, \beta$ unsaturated ketone substrates $\mathbf{2}$, substrate $\mathbf{4 a}$ with ami- no(thio)ureas 8a and $\mathbf{8 b}$ failed to produce products with an acceptable er value. Likewise, Tang's urea catalyst $\mathbf{9}^{5}$ only delivered a product with low er value. Thus, it appears that a classical double hydrogen-bond activation mechanism is not involved with this substrate. Amino-thiocarbamate<smiles>CC(=O)C(=O)c1ccccc1C(=O)O</smiles><smiles>CC1(CBr)OC(=O)c2ccccc2C1=O</smiles>

4a

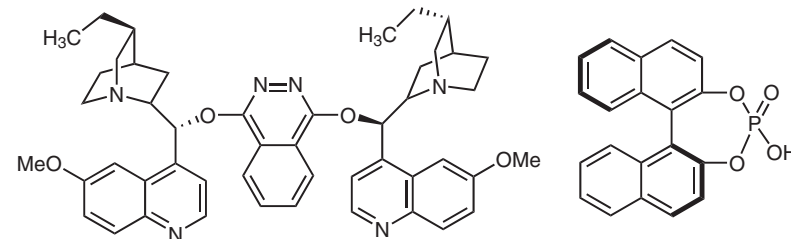

7a $91 \%$ yield, er $=53: 47$<smiles>O=C(N[Tl])Nc1ccccc1</smiles>

$$
43
$$<smiles>CNC(=S)Nc1ccccc1</smiles><smiles>[3H]NC(=O)NCC</smiles>

$\mathbf{8 b} 92 \%$ yield, er $=52: 48$

$991 \%$ yield, er $=56: 44$<smiles></smiles><smiles>BrC(c1ccnc2ccccc12)C1C=CC2CCN1C2</smiles>

7b $93 \%$ yield, er $=55: 45$<smiles>COC(=S)Nc1ccccc1</smiles>

$1093 \%$ yield, er $=55: 45$<smiles>CCOC(=O)Nc1ccccc1</smiles>

8a $96 \%$ yield, er $=54: 46$<smiles>C=CC1CN2CCC1(C)CC2C(OC(=O)Nc1ccccc1)c1ccnc2ccc(OC)cc12</smiles><smiles>C=CC1CC2CCN1C2[C@H](OC(=O)Nc1ccccc1)c1ccnc2ccc(OC)cc12</smiles><smiles>O=C(Nc1ccccc1)OC(c1cccc2ccccc12)C1CCCN1</smiles>
$1197 \%$ yield, er $=42: 58$<smiles>O[C@H](c1ccnc2ccccc12)[C@@H]1CC2CCC(C2)N1CCc1ccccc1</smiles>

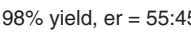

$1397 \%$ yield, er $=41: 59$

14a $99 \%$ yield, er $=53: 47$<smiles>CCC(=O)NC12CC3CC(CC(C3)C1)C2</smiles><smiles>[3H]NC(=O)[Te]C([3H])=O</smiles>

15a $98 \%$ yield, er $=60: 40$

15b $97 \%$ yield, er $=57: 43$

$15 \mathrm{c} 95 \%$ yield, er $=59: 41$<smiles>O=C(Nc1ccccc1)O[C@H](c1cccc2ccccc12)C1CCCN1</smiles>

14b $96 \%$ yield, er $=52: 48$<smiles>Cc1ccc(NC(=O)C(C)C)cc1</smiles><smiles>COc1ccc(NC(=O)C(C)C)cc1</smiles>

$15 f 98 \%$ yield, er $=64: 36$<smiles>COc1ccc(NC(=O)C(C)C)cc1OC</smiles>

$15 \mathrm{~g} \mathrm{95 \%} \mathrm{yield,} \mathrm{er}=61: 39$<smiles>COc1ccc(NC(C)=O)c(OC)c1</smiles><smiles>CCC(=O)Nc1ccc(OC)cc1C</smiles><smiles>COc1ccc(NC(=O)C(C)C)cc1OC</smiles>

$15199 \%$ yield, er $=65: 35$<smiles>CC(=O)Nc1ccc2c(c1)OCO2</smiles>

$15 \mathrm{~h} 95 \%$ yield, er $=70: 30$<smiles>CC(=O)Nc1ccc(C(F)(F)F)cc1</smiles>

$15 d$ 96\% yield, er $=56: 44$

15j $97 \%$ yield, er $=60: 40$

15k $98 \%$ yield, er $=64: 36$<smiles>CCOc1cc([N+](=O)[O-])c(NC(=O)C(C)C)c([N+](=O)[O-])c1</smiles>

$15 q 96 \%$ yield, er $=62: 38$<smiles>CCOc1ccc(NC(=O)C(C)C)cc1</smiles>

$15 \mathrm{~m} \mathrm{98} \%$ yield, er $=66: 34$<smiles>O=C(I)Nc1ccc2c(c1)OCCO2</smiles>

$15 i$ 96\% yield, er $=70: 30$<smiles>CCOc1ccc(NC(=O)C(C)C)cc1</smiles>

$15 n 97 \%$ yield, er $=65: 35$<smiles>CCOc1ccc(NC(=O)C(C)C)cc1C</smiles>

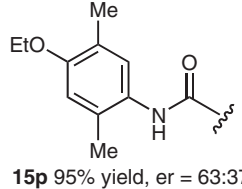<smiles>CCOc1ccc(NC(=O)CC)c([N+](=O)[O-])c1C</smiles>

$15 r$ 95\% yield, er $=65: 35$<smiles>CCOc1c(C)cc(NC(C)=O)cc1[N+](=O)[O-]</smiles>

15s $98 \%$ yield, er $=71: 29$<smiles>CC(=O)Nc1cc(C(F)(F)F)cc(C(F)(F)F)c1</smiles><smiles>CCC1CN2CCC1C2[C@H](OC(=O)Nc1ccccc1)c1ccnc2ccccc12</smiles>

Scheme 2 Study on effect of catalyst. Reactions were conducted with substrate 4 a $(0.1 \mathrm{mmol})$, catalyst $(0.015 \mathrm{mmol})$, and NBS ( $0.13 \mathrm{mmol})$ in toluene $(4 \mathrm{~mL})$ at $25^{\circ} \mathrm{C}$ for 24 hours in the absence of light. Ts $=p$-tolulenesulfonyl. Isolated yield. The er were determined by chiral HPLC. 
catalysts first reported by Yeung and co-workers, ${ }^{6}$ which have been found useful for asymmetric bromolactonization of isolated alkenes, ${ }^{7}$ also proved to be inadequate for $\alpha, \beta$ unsaturated alkene 4a (Scheme 2, 10, er = 55:45). However, the fact that a certain degree of enantioselectivity could be achieved in the presence of this catalyst indicates that Lewis base activation together with hydrogen bonding might be helpful to deliver a good er ratio. The structurally related amino-carbamate catalyst $\mathbf{1 1}$ increased the er ratio to 42:58. Further screening led us to use the cinchonine framework, which increased the er ratio to 60:40 (Scheme $2,15 a)$. Other chiral scaffolds, such as L-proline derived carbamates, generally resulted in lower enantioselectivities (Scheme 2,11-14, 15u). Thus, we focused on modifying different substituents of the carbamate moiety. The bulky admantyl carbamate decreased the er ratio (Scheme 2, 15b). Although electron-deficient carbamate catalysts have previously been shown to exhibit excellent enantioselectivity in bromolactamizations, ${ }^{7}$ such catalysts containing a Ts group, a 4- $\mathrm{CF}_{3}$-phenyl group, and a 3,5-( $\left(\mathrm{CF}_{3}\right)_{2}$-phenyl group failed to increase enantioselectivity in this case (Scheme 2 , $15 c, 15 d$ and 15t ). Conversely, carbamates with electronrich substituents, such as OMe and OEt were beneficial to this transformation. For instance, $\mathbf{1 5 f}$ and $\mathbf{1 5 m}$ returned the desired product with higher er. The inclusion of an additional methyl substituent was found to be capable of increasing the er. For example, the catalyst with a 3-methyl4-methoxyl carbamate moiety increased the enantioselectivity (Scheme 2, 15l). In particular, carbamate 15s gave the desired product 5a with 71:29 er (Scheme 2).

Subsequent studies concentrated on optimizing the reaction conditions. As shown in Table 1, the effect of additives, such as $\mathrm{BzOH}$ and $\mathrm{NsNH}_{2}$ on asymmetric bromolactonization of substrate $4 \mathbf{a}^{8}$ was detrimental, leading to lower enantioselectivities (entries 2-5). We suspect that the formation of $\mathrm{NsNHBr}$, through $\mathrm{Br}$ exchange between NBS and $\mathrm{NsNH}_{2},{ }^{6 f}$ could be the reason in the latter instance. Utilization of other solvents, such as $\mathrm{Et}_{2} \mathrm{O}, \mathrm{EtOAc}, \mathrm{CH}_{2} \mathrm{Cl}_{2}$ and $\mathrm{CHCl}_{3}$ failed to induce higher er (entries 6-9). The enantioselectivity decreased when the temperature was lowered to $0{ }^{\circ} \mathrm{C}$ (entry 10 ) but the er increased to $73: 27$ when the temperature was $15{ }^{\circ} \mathrm{C}$ (entry 11). Other halogen sources such as $\mathrm{N}$-bromophthalimide (NBP), 1,3-dibromo-5,5-dimethylhydantoin (DBDMH), $N$-bromosaccharin and 2,4,4,6tetrabromo-2,5-cyclohexadienone (TBCHD) led to inferior outcomes (entries 12-15). The amount of catalyst loading was found to be important. As demonstrated in Table 1, entry 16 , the enantioselectivity decreased when $10 \mathrm{~mol} \%$ catalyst was used. In addition, er was reduced slightly with 20 mol\% catalyst (entry 17). Unfortunately, the enantioselectivity was poor when $\mathrm{N}$-iodosuccinimide (NIS) was used instead of NBS (entry 18), while use of $N$-chlorosuccinimide (NCS, entry 20) failed to result in chlorolactonization (entry 18). However, 1,3-dichloro-5,5-dimethylhydantoin(DCDMH)
Table 1 Optimization of the Reaction Conditions ${ }^{\mathrm{a}}$

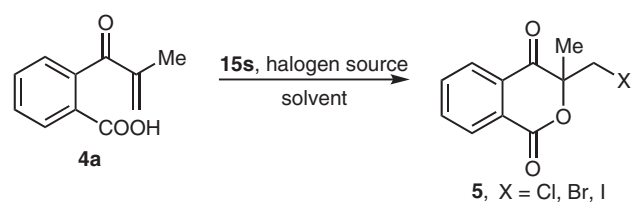

\begin{tabular}{|c|c|c|c|c|}
\hline Entry & Halogen source & Conditions & $\mathrm{Er}^{\mathrm{b}}$ & Yield (\%) \\
\hline 1 & NBS & toluene, r.t. & $71: 29$ & 98 \\
\hline 2 & NBS & $\begin{array}{l}\mathrm{BzOH}(1.0) \text {, toluene, } \\
\text { r.t. }\end{array}$ & $70: 30$ & 96 \\
\hline 3 & NBS & $\begin{array}{l}\mathrm{BzOH}(0.5) \text {, toluene, } \\
\text { r.t. }\end{array}$ & $70: 30$ & 97 \\
\hline 4 & NBS & $\begin{array}{l}\mathrm{NsNH}_{2}(1.0) \text {, toluene, } \\
\text { r.t. }\end{array}$ & $67: 33$ & 97 \\
\hline 5 & NBS & $\begin{array}{l}\mathrm{NsNH}_{2}(0.5) \text {, toluene, } \\
\text { r.t. }\end{array}$ & $68: 32$ & 98 \\
\hline 6 & NBS & $\mathrm{Et}_{2} \mathrm{O}$, r.t. & $64: 36$ & 95 \\
\hline 7 & NBS & EtOAc, r.t. & $61: 39$ & 99 \\
\hline 8 & NBS & $\mathrm{CH}_{2} \mathrm{Cl}_{2}$, r.t. & $59: 41$ & 99 \\
\hline 9 & NBS & $\mathrm{CHCl}_{3}$, r.t. & $58: 42$ & 99 \\
\hline 10 & NBS & toluene, $0^{\circ} \mathrm{C}$ & $69: 31$ & 98 \\
\hline 11 & NBS & toluene, $15^{\circ} \mathrm{C}$ & 73:27 & 99 \\
\hline 12 & NBP & toluene, $15^{\circ} \mathrm{C}$ & $72: 78$ & 97 \\
\hline 13 & DBDMH & toluene, $15^{\circ} \mathrm{C}$ & $65: 35$ & 98 \\
\hline 14 & $\mathrm{~N}$-Bromosaccharin & toluene, $15^{\circ} \mathrm{C}$ & $64: 36$ & 95 \\
\hline 15 & $\mathrm{TBCHD}$ & toluene, $15^{\circ} \mathrm{C}$ & $61: 39$ & 96 \\
\hline $16^{d}$ & NBS & toluene, $15^{\circ} \mathrm{C}$ & $71: 29$ & 97 \\
\hline $17^{e}$ & NBS & toluene, $15{ }^{\circ} \mathrm{C}$ & $70: 73$ & 99 \\
\hline $18^{f}$ & NIS & toluene, $15^{\circ} \mathrm{C}$ & $56: 44$ & 98 \\
\hline 19 & NCS & toluene, $15^{\circ} \mathrm{C}$ & - & $<5$ \\
\hline $20^{9}$ & DCDMH & toluene, $15^{\circ} \mathrm{C}$ & $48: 52$ & 77 \\
\hline
\end{tabular}

a Reactions were carried out with substrate $4 \mathrm{a}(0.1 \mathrm{mmol})$, catalyst $15 \mathrm{~s}$ $(0.015 \mathrm{mmol})$, and halogen source $(0.13 \mathrm{mmol})$ in solvent $(4.0 \mathrm{~mL})$ in the absence of light. The amount of $\mathrm{BzOH}$ and $\mathrm{NsNH}_{2}$ was 1.0 or 0.5 equiv.

b The er was determined by chiral HPLC.

' Isolated yield.

${ }^{\mathrm{d}}$ The amount of catalyst $15 \mathrm{~s}$ was $0.01 \mathrm{mmol}$.

e The amount of catalyst $15 \mathrm{~s}$ was $0.02 \mathrm{mmol}$.

${ }^{\mathrm{f}} \mathrm{N}$-lodosuccinimide (NIS) was used as halogen source. The corresponding iodolactone was obtained instead of the bromolactone.

9 1,3-Dichloro-5,5-dimethylhydantoin (DBDMH) was used as halogen source. The corresponding chlorolactone was obtained instead of the bromolactone

could be used to perform the chlorolactonization and produced the desired chloro-substituted isochroman-1,4-dione in $77 \%$ yield (entry 19 ).

The scope of bromolactonization substrates $\mathbf{4 a - m}$ is illustrated by the examples in Scheme $3 .{ }^{9}$ Generally, moderate enantioselectivities were obtained for alkyl substituents, such as Me, Et, $n$-Pr, $i$-Pr, $n$-Bu and allyl groups $\left(\mathrm{R}^{2}\right.$ group). The er was 20:80 when the $n$-Pr substituent was present (Scheme 3, 4c). However, lower enantioselectivities 
were induced when the $\mathrm{R}^{2}$ group was benzyl or a phenyl (Scheme 3, 4e and 4f). The yield dropped considerably when $R^{2}$ was allyl (Scheme 3, 4i), suggesting that the carbon-carbon double bond of the allyl moiety might also be involved in bromolactonization, generating significant amounts of side-products leading to the failure to isolate pure isochroman-1,4-dione $4 \mathbf{i}$. An er of 24:76 could be obtained when the benzoic acid possessed 3,4-dichlorosubstitution (Scheme 3, 4m).

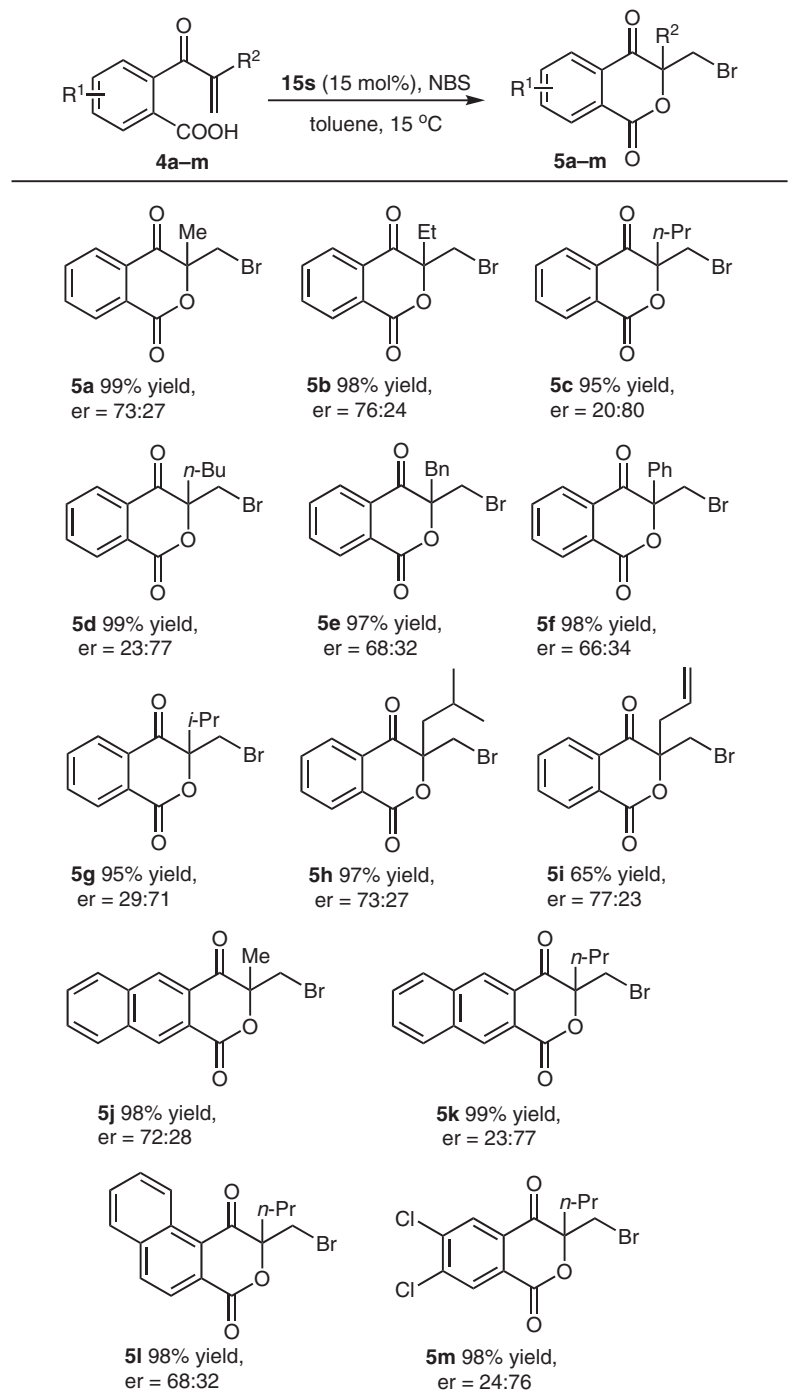

Scheme 3 Substrate scope. Reactions were conducted with substrate $4 a(0.2 \mathrm{mmol})$, catalyst $(0.03 \mathrm{mmol})$, and NBS $(0.26 \mathrm{mmol})$ in toluene $(8 \mathrm{~mL})$ at $15^{\circ} \mathrm{C}$ for 36 hours in the absence of light. Isolated yields are given. The er was determined by chiral HPLC.

To gain insight into the reaction mechanism, carbamate 16 was exposed to NBS solution; however, mass spectrometry did not indicate the formation of 16-Br (Scheme 4a), indicating that a species such as $\mathbf{1 6 - B r}$ might not be the active brominating species in the reaction. Based on the study by Yeung and co-workers, ${ }^{6 f}$ this simple carbamate can be used to catalyze bromolactonization, albeit with a slower reaction rate compared with the thiocarbamate catalyst. We suspect that the oxygen Lewis base might be able to activate NBS. A plausible reaction mechanism is shown in Scheme $4 \mathrm{~b}$. Thus, chiral transition state $\mathbf{A}$ might be formed in which the $\mathrm{NH}$ generates a hydrogen bond with a carbonyl group of NBS. The oxygen Lewis base might thus interact with the Br on NBS during the process of enantioselective bromocyclization. Substrate $\mathbf{4}$ contains a carboxylic acid group, which might coordinate with the basic nitrogen of the quinuclidine moiety. The role of oxygen Lewis base, however, remains unclear and will be the subject of further investigation.

a)<smiles>CC(C)COC(=O)NNc1ccccc1</smiles>

b)<smiles>COc1cc(C)cc([N+](=O)[O-])c1OC</smiles>

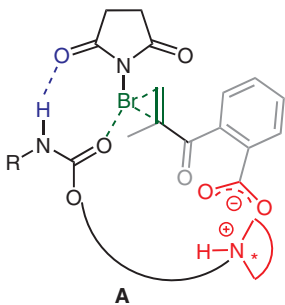

Scheme 4 Proposed reaction mechanism

In summary, we have described an enantioselective protocol to produce synthetically valuable brominated isochroman-1,4-diones with excellent yields and moderate enantioselectivities. The results shed some light on the design of chiral carbamate catalysts for asymmetric halolactonization of deactivated olefinic acids.

\section{Funding Information}

We thank the Natural Science Foundation of Guangdong Province (Grant No. 2017B050506006) and Fundamental Research Funds for the Central University (Grant No. 21617470) for financial support.

\section{Supporting Information}

Supporting information for this article is available online at https://doi.org/10.1055/s-0037-1610401. 


\section{References and Notes}

(1) (a) Barcia, J. C.; Cruces, J.; Estévez, J. C.; Estévez, R. J.; Castedo, L. Tetrahedron Lett. 2002, 43, 5141. (b) Uyanik, M.; Yasui, T.; Ishihara, K. Bioorg. Med. Chem. Lett. 2009, 19, 3848. (c) Yang, R.Y.; Kizer, D.; Wu, H.; Volckova, E.; Miao, X.-S.; Ali, S. M.; Tandon, M.; Savage, R. E.; Chan, T. C. K.; Ashwell, M. A. Bioorg. Med. Chem. 2008, 16, 5635. (d) Egan, B. A.; Paradowski, M.; Thomas, L. H.; Marquez, R. Org. Lett. 2011, 13, 2086. (e) Hobson, S. J.; Parkin, A.; Marquez, R. Org. Lett. 2008, 10, 2813. (f) Faizi, D. J.; Issaian, A.; Davis, A.; Blum, S. A. J. Am. Chem. Soc. 2016, 138, 2126. (g) Miyaka, H.; Nishimura, A.; Yago, M.; Sasaki, M. Chem. Lett. 2007, 36, 332. (h) Warrener, R. N.; Liu, L.; Russell, R.; Tiekink, E. R. T. Synlett 1998, 387.

(2) Zhu, T.-S.; Chen, J.-P.; Xu, M.-H. Chem. Eur. J. 2013, 19, 865.

(3) For selective reviews, see: (a) Cheng, Y. A.; Yu, W. Z.; Yeung, Y.-Y. Org. Biomol. Chem. 2014, 12, 2333. (b) Tan, C. K.; Yu, W. Z.; Yeung, Y.-Y. Chirality 2014, 26, 328. (c) Murai, K.; Fujioka, H. Heterocycles 2013, 87, 763. (d) Tan, C. K.; Yeung, Y.-Y. Chem. Commun. 2013, 7985. (e) Chemler, S. R.; Bovino, M. T. ACS Catal. 2013, 3, 1076. (f) Denmark, S. E.; Kuester, W. E.; Burk, M. T. Angew. Chem. Int. Ed. 2012, 51, 10938. (g) Hennecke, U. Chem. Asian J. 2012, 7, 456. (h) Castellanos, A.; Fletcher, S. P. Chem. Eur. J. 2011, 17, 5766. (i) Tan, C. K.; Zhou, L.; Yeung, Y.-Y. Synlett 2011, 1335. (j) Zheng, S.; Schienebeck, C. M.; Zhang, W.; Wang, H.-Y.; Tang, W. Asian J. Org. Chem. 2014, 3, 366. (k) Sakakura, A.; Ishihara, K. Chem. Rec. 2015, 15, 728.

(4) Jiang, X.; Liu, S.; Yang, S.; Jing, M.; Xu, L.; Yu, P.; Wang, Y.; Yeung, Y.-Y. Org. Lett. 2018, 20, 3259.

(5) Zhang, W.; Zheng, S.; Liu, N.; Werness, J. B.; Guzei, I. A.; Tang, W. J. Am. Chem. Soc. 2010, 132, 3664.

(6) (a) Jiang, X.; Tan, C. K.; Zhou, L.; Yeung, Y.-Y. Angew. Chem. Int. Ed. 2012, 51, 7771. (b) Zhao, Y.; Jiang, X.; Yeung, Y.-Y. Angew. Chem. Int. Ed. 2013, 52, 8597. (c) Tan, C. K.; Le, C.; Yeung, Y.-Y. Chem. Commun. 2012, 5793. (d) Chen, J.; Zhou, L.; Tan, C. K.; Yeung, Y.-Y.J. Org. Chem. 2012, 77, 999. (e) Tan, C. K.; Zhou, L.; Yeung, Y.-Y. Org. Lett. 2011, 13, 2738. (f) Zhou, L.; Tan, C. K.; Jiang, X.; Chen, F.; Yeung, Y.-Y. J. Am. Chem. Soc. 2010, 132, 15474. (g) Zhou, L.; Chen, J.; Tan, C. K.; Yeung, Y.-Y.J. Am. Chem. Soc. 2011, 133, 9164. (h) Chen, J.; Zhou, L.; Yeung, Y.-Y. Org. Biomol. Chem. 2012, 10, 3808. (i) Zhou, L.; Tay, D. W.; Chen, J.; Leung, G. Y. C.; Yeung, Y.-Y. Chem. Commun. 2013, 4412.
(7) Cheng, Y. A.; Yu, W. Z.; Yeung, Y.-Y. Angew. Chem. Int. Ed. 2015, 54, 12102.

(8) Representative Procedure for Generating $\alpha, \beta$-Unsaturated Ketone 4a: To a solution of keto acid $\mathbf{A}$ (3.0 mmol, 1.0 equiv) in acetic acid $(6 \mathrm{~mL})$ was added pyrrolidine $(0.1 \mathrm{~mL}, 1.2 \mathrm{mmol}, 0.4$ equiv) and formaldehyde solution (36.5-38\% in $\mathrm{H}_{2} \mathrm{O}, 1 \mathrm{~mL}, 13.2 \mathrm{mmol}$, 4.4 equiv) at room temperature. The mixture was then stirred for $48 \mathrm{~h}$ at $85^{\circ} \mathrm{C}$. After evaporation of the acetic acid, water and EtOAc were added. The organic layer was washed with water, dried over magnesium sulphate and filtered. Concentration of the organic layer afforded the crude product, which was further purified by flash column chromatography (hexane/EtOAc) to give the corresponding $\alpha, \beta$-unsaturated ketone $4 a$. Yield: 427.5 mg (75\%); yellow solid; mp $125-126{ }^{\circ} \mathrm{C}$; ${ }^{1} \mathrm{H}$ NMR $\left(\mathrm{CDCl}_{3}, 300\right.$ $\mathrm{MHz}): \delta=10.84(\mathrm{br} / \mathrm{s}, 1 \mathrm{H}), 8.09-7.33(\mathrm{~m}, 4 \mathrm{H}), 5.80(\mathrm{~s}, 1 \mathrm{H})$, $5.30(\mathrm{~s}, 1 \mathrm{H}), 2.07(\mathrm{~s}, 3 \mathrm{H}) ;{ }^{13} \mathrm{C}$ NMR $\left(\mathrm{CDCl}_{3}, 75 \mathrm{MHz}\right): \delta=199.2$, 170.9, 145.9, 142.7, 133.2, 130.8, 129.4, 127.8, 127.7, 127.6, 17.4; HRMS (TOF-): $\mathrm{m} / z$ [M - 1] $]^{-}$calcd for $\mathrm{C}_{11} \mathrm{H}_{9} \mathrm{O}_{3}: 189.0562$; found: 189.0561

(9) Representative Procedure for Generating Isochroman-1,4-dione 5a: To a solution of $\alpha, \beta$-unsaturated ketone $4 a(38 \mathrm{mg}, 0.2$ mmol, 1.0 equiv) and catalyst $15 \mathrm{~s}(14.6 \mathrm{mg}, 0.03 \mathrm{mmol}, 0.15$ equiv)in toluene $(8 \mathrm{~mL})$, at $15^{\circ} \mathrm{C}$, in the dark under nitrogen was added NBS ( $46 \mathrm{mg}, 0.26 \mathrm{mmol}, 1.3$ equiv). The resulting mixture was stirred at $15^{\circ} \mathrm{C}$ and monitored by TLC. The reaction was quenched with saturated $\mathrm{Na}_{2} \mathrm{SO}_{3}(1 \mathrm{~mL})$ at $15^{\circ} \mathrm{C}$ and then was allowed to warm to room temperature. The mixture was diluted with water $(3 \mathrm{~mL})$, extracted with EtOAc, dried over $\mathrm{MgSO}_{4}$, filtered and concentrated in vacuo. The residue was purified by flash column chromatography (hexane/EtOAc) to yield the corresponding isochroman-1,4-dione 5a. Yield: $53.1 \mathrm{mg}$ (99\%); yellow oil; $[\alpha]_{\mathrm{D}}{ }^{25}=4.9$ (c 1.0, MeOH, 73:27 er); ${ }^{1} \mathrm{H} \mathrm{NMR}\left(\mathrm{CDCl}_{3}\right.$, $300 \mathrm{MHz}): \delta=8.32-7.83(\mathrm{~m}, 4 \mathrm{H}), 3.99\left(\mathrm{dd}, J_{1}=9.0 \mathrm{~Hz}, J_{2}=\right.$ 93.0 Hz, $2 \mathrm{H}), 1.78(\mathrm{~s}, 3 \mathrm{H}) ;{ }^{13} \mathrm{C} \mathrm{NMR}\left(\mathrm{CDCl}_{3}, 75 \mathrm{MHz}\right): \delta=192.3$, 160.9, 135.9, 134.7, 130.7, 130.6, 126.6, 126.4, 87.6, 37.4, 25.4; HRMS $\left(\mathrm{TOF}^{+}\right): \mathrm{m} / z[\mathrm{M}+\mathrm{H}]^{+}$calcd. for $\mathrm{C}_{11} \mathrm{H}_{10} \mathrm{BrO}_{3}: 269.1377$; found: 269.1378; HPLC (Daicel Chiralcel AD-H; $i-\mathrm{PrOH} /$ hexane $=$ $10: 90,1.0 \mathrm{~mL} / \mathrm{min}, 254 \mathrm{~nm}$ ): $t_{1}=8.6 \mathrm{~min}$ (major), $t_{2}=9.5 \mathrm{~min}$ (minor) 